\title{
RADIOCARBON ACCELERATOR (AMS) DATES FOR THE EPIPALEOLITHIC SETTLEMENT AT ABU HUREYRA, SYRIA
}

\author{
A M T MOORE*, J A J GOWLETT**, R E M HEDGES**, \\ G C HILLMAN†, A J LEGGE + and P A ROWLEY-CONWY +
}

ABSTRACT. The prehistoric settlement of Abu Hureyra in Syria was occupied in both the Epipaleolithic and Neolithic periods. It has provided significant evidence for changes in economy at the time of the inception of agriculture in southwest Asia. Twenty accelerator mass spectrometry (AMS) dates have been obtained to determine the duration of occupation of the Epipaleolithic settlement there and the precise age of samples of cereal grains and animal bones found within it. The results have demonstrated that the AMS technique can answer such questions because it dates exceedingly small samples with high precision. The dates indicate that the Epipaleolithic settlement was inhabited for about a millennium, from before 11,000 to nearly $10,000 \mathrm{BP}$, significantly longer than had been anticipated from study of the artifacts.

The Radiocarbon Accelerator Unit of the Research Laboratory for Archaeology and the History of Art at the University of Oxford has recently obtained a series of ${ }^{14} \mathrm{C}$ accelerator (AMS) dates for samples recovered from the Epipaleolithic settlement at Abu Hureyra in Syria. These dates are of great value in interpreting the material record from Abu Hureyra and illustrate well the potential of this new method for addressing problems in archaeologic research. The purpose of this paper is to explain why the series of dates was obtained, to publish the dates in full, and to use them to define the duration of occupation of the Epipaleolithic settlement.

Abu Hureyra $\left(35^{\circ} 52^{\prime} \mathrm{N} 38^{\circ} 24^{\prime} \mathrm{E}\right.$ ) is a very large (ca 11.5ha) prehistoric mound in the valley of the Euphrates River (Fig 1). It was excavated in 1972 and 1973 as part of a campaign of salvage archaeology organized by the Syrian Directorate-General of Antiquities and Museums prior to the completion of a dam across the Euphrates. The site was flooded in 1974, bringing field research to an end. The large quantities of artifacts and organic remains recovered in the excavation are currently being analyzed and preparation of the final reports is underway.

The excavation revealed that the site had been inhabited twice (Moore, $1975,1979)$. The first occupation consisted of an Epipaleolithic (Mesolithic) settlement of pit dwellings, found in Trench E. The nature of the associated finds, in particular, a chipped stone assemblage with high proportions of microlithic lunates, indicated that this settlement had been inhabited during the second stage of the Levantine Epipaleolithic sequence, Epipaleolithic 2 (Moore, 1983). This settlement was later abandoned and, after an interval, a second one was founded at Abu Hureyra during the earlier Neolithic. This village was occupied for much of Neolithic 2 and part of Neolithic 3 in the Levantine sequence (Moore, 1982).

The excavation of Abu Hureyra has allowed us to address a series of key issues in southwest Asian prehistoric archaeology in a scientifically rig-

* Department of Anthropology, Yale University, New Haven, Connecticut 06520

** Radiocarbon Accelerator Unit, Research Laboratory for Archaeology and the History of Art, 6 Keble Road, Oxford OX1 3QJ, England

+ Department of Human Environment, Institute of Archaeology, University of London, 31-34 Gordon Square, London WC1H OPY, England

+ Department of Extra-Mural Studies, University of London, 26 Russell Square, London WC1B 5DQ, England 


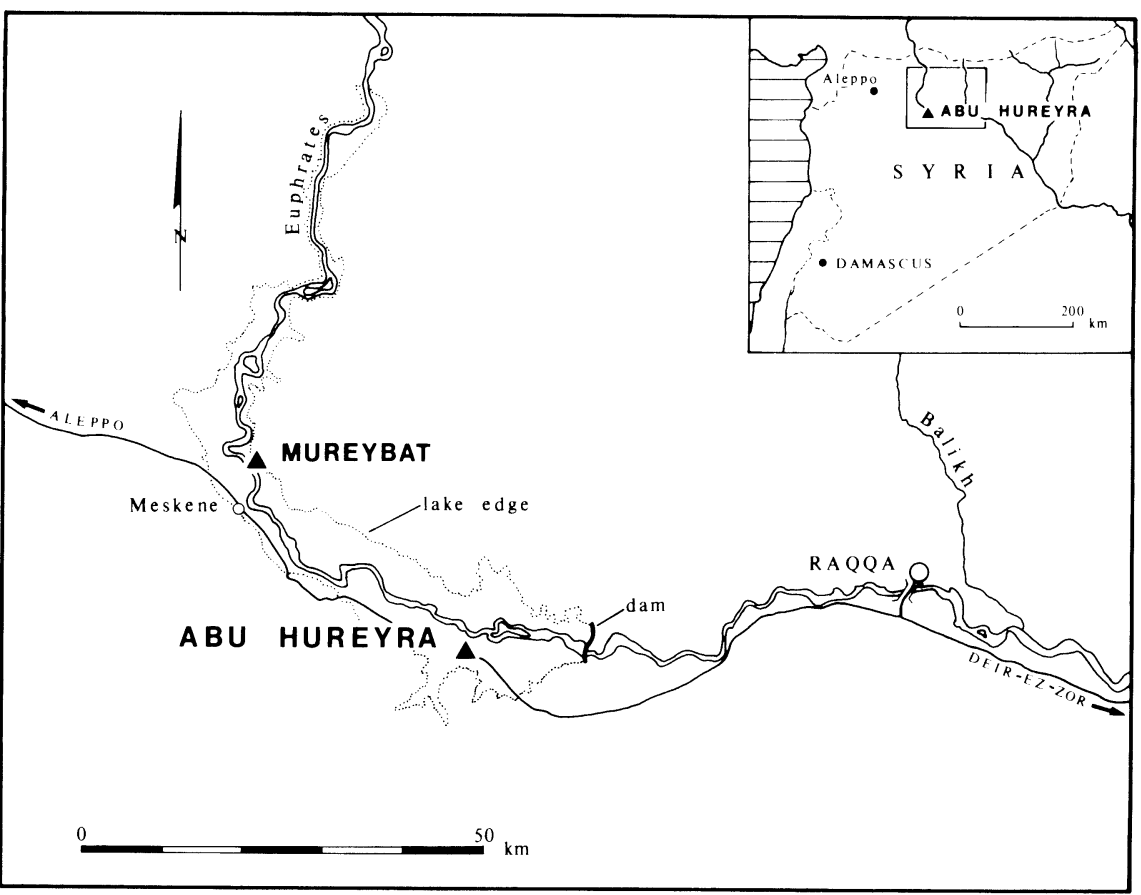

Fig 1. The location of Abu Hureyra in Syria

orous manner. There are four reasons for this. First, the site has yielded an unusually long occupation sequence with evidence pertaining to a crucial episode of cultural and economic change in this region, namely the transition from Epipaleolithic to Neolithic and from hunting and gathering in the late Pleistocene to farming in the early Holocene. Second, the rich samples of animal bones and carbonized seeds systematically recovered in the excavation by sieving and flotation have permitted us to examine precise details of changes in subsistence during these critical periods. Third, the Epipaleolithic settlement was quite large while the Neolithic village was of extraordinary size, the most substantial, indeed, of all known Neolithic sites in the Levant. This is important for the information it provides on site function and social organization. Fourth, the structures and artifacts of both settlements were very well preserved, allowing detailed reconstruction of the domestic arrangements and activities of their inhabitants.

The evidence for changes in the economy from Epipaleolithic to Neolithic is of special interest. Hillman's (1975) study of the plant remains indicates that the inhabitants of the Epipaleolithic settlement engaged in exceedingly intensive collection of a wide variety of plant foods, both from the surrounding steppe and the Euphrates valley. Furthermore, Abu Hureyra has provided a unique opportunity to examine hunting and husbandry practices in both Epipaleolithic and Neolithic levels (Legge, 1975). 
Samples of wood charcoal for dating were collected during the excavation in order that an outline ${ }^{14} \mathrm{C}$ chronology might be determined for the sequence of occupation at the site. Two series of samples from both the Epipaleolithic and Neolithic settlements were submitted to the British Museum Research Laboratory and a total of 13 dates obtained and published (Burleigh, Matthews \& Ambers, 1982; Burleigh, Ambers \& Matthews, 1982). These dates indicated that the Epipaleolithic settlement was occupied ca 11,000 BP and the Neolithic village from before $9000 \mathrm{BP}$ until after $8000 \mathrm{BP}$. The dates were quite satisfactory as a series, although one or two were obviously aberrant and there were inconsistencies between dates from virtually contemporary levels in the Neolithic settlement. There was a more general problem, however, that concerned the nature of the samples themselves. Wood charcoal was relatively scarce in the deposits at Abu Hureyra and, where found, consisted of small pieces only. Thus, the samples collected specifically for dating contained barely enough charcoal for adequate age determinations. All the samples from Abu Hureyra that had enough charcoal for conventional ${ }^{14} \mathrm{C}$ dating were processed by the British Museum Laboratory. These dates for the Epipaleolithic settlement are listed in Table 1. The date, 10, $792 \pm 82 \mathrm{BP}$, was the first to be obtained for this settlement. Charcoal was so scarce that samples from six levels representing the entire Epipaleolithic stratigraphic sequence had to be amalgamated to provide enough for a single determination. The result gave an approximate date for occupation of the Epipaleolithic settlement. The charcoal sample for the date, $11,160 \pm 110 \mathrm{BP}$, came from a basal Epipaleolithic level which indicated when the settlement was founded. Level 254 was near the surface of the Epipaleolithic settlement but the date from it, $9120 \pm 50 \mathrm{BP}$, is clearly too late for such a context. The Epipaleolithic settlement was overlain directly by Neolithic levels. It is likely that some charcoal from the Neolithic settlement was present in the uppermost Epipaleolithic levels which accounts for the late date.

These dates approximated when the Epipaleolithic settlement was inhabited but they did not tell us how long the site was occupied. Further questions have arisen that concern the dating of the plant and faunal remains. For example, researchers (Hillman et al, The results of pyrolysis mass spectrometry of modern and ancient wheats of three different ploidies, ms in preparation) are presently trying to establish whether, during the Epipaleolithic at Abu Hureyra wild einkorn, Triticum boeoticum, shows any

TABle 1

Conventional radiocarbon dates for the Epipaleolithic settlement at Abu Hureyra

\begin{tabular}{lcccc}
\hline Level no. & $\begin{array}{c}\text { Nature of } \\
\text { deposit }\end{array}$ & $\begin{array}{c}\text { Sample } \\
\text { material }\end{array}$ & Date BP & Lab no. \\
\hline $264,265,266$, & Occupation soil & $\begin{array}{l}\text { Wood charcoal } \\
\text { (various spp) }\end{array}$ & $10,792 \pm 82$ & BM-1121 \\
$267,281,307$ & Occupation soil & $\begin{array}{l}\text { Wood charcoal } \\
\text { (various spp) }\end{array}$ & $9120 \pm 50$ & BM-1719 \\
303 & Occupation soil & $\begin{array}{l}\text { Wood charcoal } \\
\text { (various spp) }\end{array}$ & $11,160 \pm 110$ & BM-1718 \\
\hline
\end{tabular}


signs of systematic chemical change that might be attributable to selective pressures of cultivation. Any such changes would provide more reliable proof of the beginnings of cultivation than would conventional, morphologic indicators of domestication which, under certain forms of primitive husbandry, would never become manifest. In exploring these subtle, diachronic changes indicative of such momentous alterations in human economy, it is clearly desirable to date a stratified series of einkorn grains directly rather than to rely on the indirect association of seeds with dated wood charcoal from the same levels. Accordingly, we carefully selected samples of einkorn grain from a series of levels of the Epipaleolithic deposits. Each sample consisted of fragments collectively equivalent to three whole grains. These fragments were, however, selected only in cases where their identity as Triticum boeoticum was not in doubt. Similarly, it was important to establish a chronology for the potentially domestic species of fauna, in particular shecp, by dating individual bones, rather than simply to assume that none had intruded into the earlier Neolithic and Epipaleolithic levels (Legge \& Rowley-Conwy, in press).

The AMS technique offers the great advantage that it is capable of dating exceedingly small samples of organic material containing ${ }^{14} \mathrm{C}$. (Hedges, 1981; Hedges \& Gowlett, 1986). This means that individual seeds and bones as well as artifacts may be dated directly. Hitherto, objects could usually only be dated by association with a radiocarbon sample of known age in the same archaeologic level, with all the errors inherent in such estimations. Furthermore, AMS dates can now be obtained with such precision that problems of change through time may satisfactorily be resolved in an archaeologic sequence no more than several centuries long.

The Radiocarbon Accelerator Unit of the University of Oxford has already developed considerable experience with the technique (Gillespie $e$ l al, 1984, 1985) and has aimed to minimize the sources of crror inherent in the dating process. The Oxford Laboratory dated a series of samples from Abu Hureyra in order to answer our particular questions concerning the changing economy and duration of occupation of the Epipaleolithic settlement. Twenty dates have been obtained from 12 samples from 10 levels in the Epipaleolithic deposits, with most satisfactory results (Table 2). The samples of wild einkorn grains were derived from material recovered in flotation. The bone samples were recovered in excavating and dry sieving occupation levels. Some of the AMS dates obtained from the humic fraction of the samples differ significantly from the residue dates themselves, but humic dates are considered to be a somewhat less reliable indicator of the true age of a sample, especially if disturbance or percolation of younger material is a factor (Batten et al, 1986), as at Abu Hureyra.

The AMS and conventional dates are plotted in stratigraphic order in Figure 2. The AMS dates themselves form a good series in the correct sequence, with the significant exceptions only of OxA-170 and OxA-386. There is considerable overlap between the dates at the level of confidence of the laboratory standard deviation, which is to be expected in samples from a settlement that was occupied intensively for a relatively short period of time. 
TABLE 2

AMS dates for the Epipaleolithic settlement at Abu Hureyra, listed in stratigraphic order

\begin{tabular}{|c|c|c|c|c|}
\hline $\begin{array}{l}\text { Level } \\
\text { no. }\end{array}$ & $\begin{array}{c}\text { Nature of } \\
\text { deposit }\end{array}$ & $\begin{array}{l}\text { Sample } \\
\text { material }\end{array}$ & Date вP & Lab no. \\
\hline 252 & $\begin{array}{l}\text { Occupation soil; } \\
\text { top level of Epi- } \\
\text { paleolithic set- } \\
\text { tlement }\end{array}$ & Charred gazelle bone & $9060 \pm 140$ & OxA-475 \\
\hline 261 & Occupation soil & $\begin{array}{l}\text { Carbonized grain fragments } \\
\text { of wild einkorn }\end{array}$ & $10,600 \pm 200$ & OxA-170 \\
\hline 275 & Occupation soil & Charred wild sheep bone & $10,050 \pm 180$ & OxA-407 \\
\hline 275 & Occupation soil & Humic fraction of $\mathrm{OxA}-407$ & $10,250 \pm 160$ & OxA-408 \\
\hline 275 & Occupation soil & Humic fraction of $\mathrm{OxA}-407$ & $10,620 \pm 150$ & $\mathrm{O} \times \mathrm{A}-471$ \\
\hline 276 & Occupation soil & $\begin{array}{l}\text { Carbonized grain fragments } \\
\text { of wild einkorn }\end{array}$ & $10,800 \pm 160$ & OxA-386 \\
\hline 281 & Occupation soil & Charred wild sheep bone & $10,000 \pm 170$ & $\mathrm{O} \times \mathrm{A}-473$ \\
\hline 281 & Occupation soil & Humic fraction of $\mathrm{O} \times \mathrm{A}-473$ & $10,750 \pm 170$ & $\mathrm{O} \times \mathrm{A}-472$ \\
\hline 285 & Occupation soil & $\begin{array}{l}\text { Humic fraction of charred } \\
\text { wild sheep bone }\end{array}$ & $10,930 \pm 150$ & OxA-474 \\
\hline 286 & Occupation soil & $\begin{array}{l}\text { Carbonized grain fragments } \\
\text { of wild einkorn }\end{array}$ & $10,420 \pm 140$ & OxA-397 \\
\hline 286 & Occupation soil & Charred gazelle bone & $10,490 \pm 150$ & $\mathrm{O} \times \mathrm{A}-434$ \\
\hline 286 & Occupation soil & Humic fraction of $\mathrm{OxA}-434$ & $10,450 \pm 180$ & OxA-435 \\
\hline 313 & Occupation soil & $\begin{array}{l}\text { Carbonized grain fragments } \\
\text { of wild einkorn }\end{array}$ & $10,600 \pm 200$ & OxA-171 \\
\hline 316 & $\begin{array}{l}\text { Occupation soil, } \\
\text { covering hearth } \\
\text { platform beside } \\
\text { pits }\end{array}$ & Charred gazelle bone & $11,020 \pm 150$ & $\mathrm{O} \times \mathrm{A}-430$ \\
\hline 316 & $\begin{array}{l}\text { Occupation soil, } \\
\text { covering hearth } \\
\text { platform beside } \\
\text { pits }\end{array}$ & Humic fraction of OxA-430 & $10,680 \pm 150$ & OxA-431 \\
\hline 326 & $\begin{array}{l}\text { Occupation soil } \\
\text { in basal pit }\end{array}$ & $\begin{array}{l}\text { Carbonized grain fragments } \\
\text { of wild einkorn }\end{array}$ & $10,900 \pm 200$ & OxA-172 \\
\hline 326 & $\begin{array}{l}\text { Occupation soil } \\
\text { in basal pit }\end{array}$ & Charred Bos sp bone & $11,070 \pm 160$ & OxA-387 \\
\hline 326 & $\begin{array}{l}\text { Occupation soil } \\
\text { in basal pit }\end{array}$ & Charred Bos sp bone, repeat & $11,090 \pm 150$ & $\mathrm{OxA}-468$ \\
\hline 326 & $\begin{array}{l}\text { Occupation soil } \\
\text { in basal pit }\end{array}$ & Humic fraction of $\mathrm{O} \times \mathrm{A}-468$ & $10,920 \pm 140$ & OxA-469 \\
\hline 326 & $\begin{array}{l}\text { Occupation soil } \\
\text { in basal pit }\end{array}$ & Humic fraction of $\mathrm{O} \times \mathrm{A}-468$ & $10,820 \pm 160$ & $0 \times A-470$ \\
\hline
\end{tabular}

The AMS dates demonstrate that outstanding chronologic problems may be satisfactorily resolved with this method using samples excavated a dozen years before. The British Museum and Oxford series' are in close agreement. The standard deviations for the British Museum dates range from 50 to 100 years, indicating that conventional ${ }^{14} \mathrm{C}$ technique can still offer a tightly defined determination. The standard deviations for the AMS dates are calculated on a different basis, and are intended to be largely inclusive (Gillespie et al, 1985, p 237). The Oxford Laboratory is now able to quote standard deviations equivalent to an error of \pm 80 to \pm 160 years.

The British Museum dates were all obtained from wood charcoal. The species of the wood was not determined beforehand but is likely to have been poplar, tamarisk, or some other valley bottom tree since all the other 


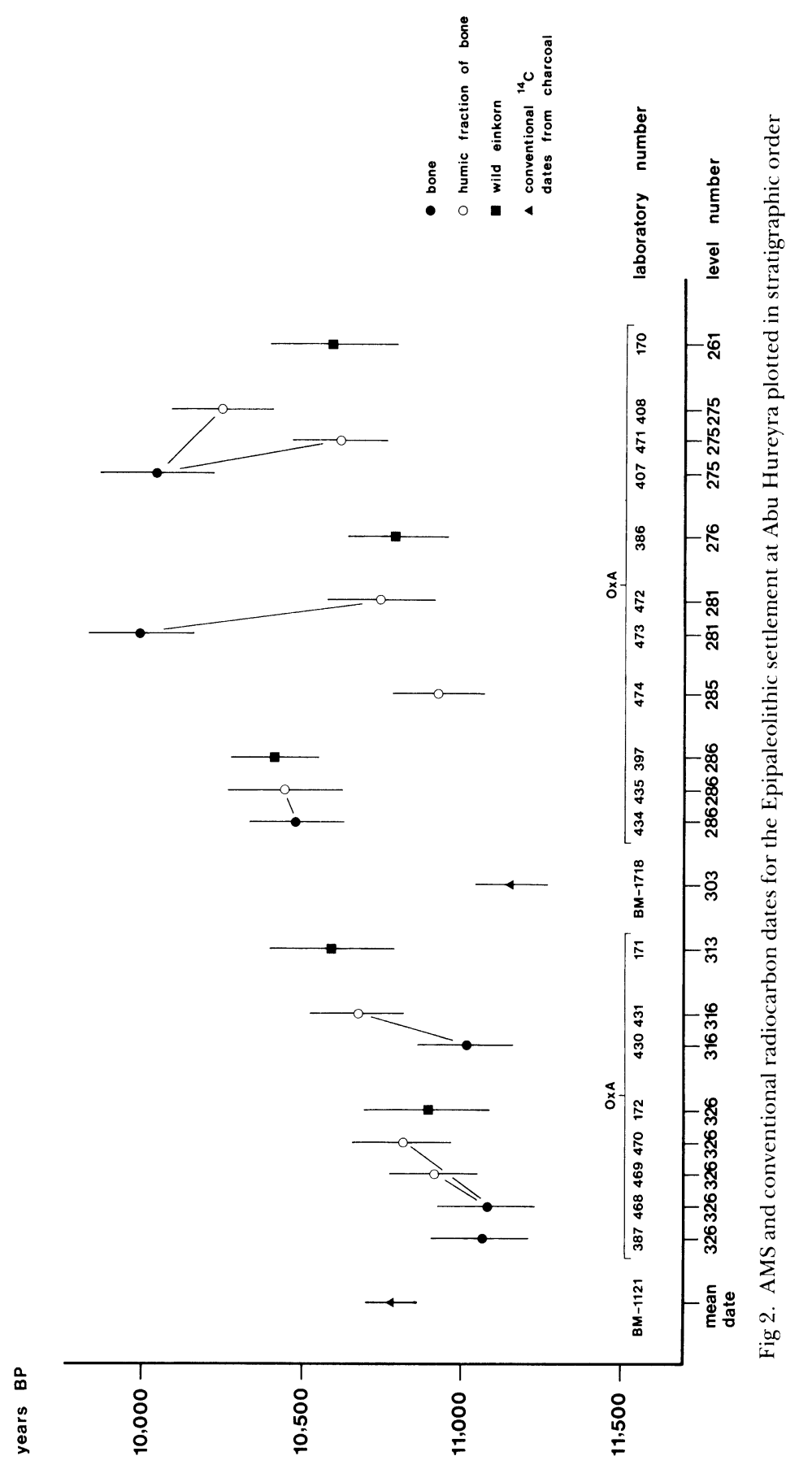


charcoal identified so far from Abu Hurcyra by K Alvin came from these species. A date on charcoal of this kind will reflect the age of the parent wood and may be significantly older than the date of deposit in the level from which it was recovered. The AMS dates were obtained from einkorn grains and bones of sheep, cattle, and gazelle that probably became incorporated in the settlement debris soon after they were harvested or killed. Thus, these dates are likely to be virtually contemporary with the deposits from which the seed and bone samples were recovered. This systematic difference is apparent when the two series of dates are compared. The oldest conventional date, BM-1718, from a level towards the bottom of the deposit, is much earlier than OxA-171 from a level of almost the same age and slightly earlier, even, than $0 \times \mathrm{xA}-468$ from a level at the very bottom of the settlement.

The occupation levels of the Epipaleolithic settlement were somewhat disturbed by burrowing rodents and human activity. This probably accounts for the presence of a few grains of domestic barley, Hordeum vulgare (Hillman, 1975, p 72), and several Neolithic flint tools in these levels which could have filtered down from the overlying Neolithic settlement. It is possible that the seeds dated in $0 \times \mathrm{AA}-170$ and $\mathrm{O} \times \mathrm{A}-386$ could have been brought up from a lower level through such movements. Yet these sources of disturbance seem not to have markedly affected the stratigraphic position of most of the seeds and bones dated by the accelerator.

It is possible to establish the approximate duration of occupation of the Epipaleolithic settlement from the sequence of dates in Figure 2. OxA$172,-387$, and -468 all date the same basal pit level. On the basis of these dates, and taking into account BM-1718, it is likely that the settlement was founded a little before $11,100 \mathrm{BP}$.

The date for the termination of occupation is more problematic. It clearly was in the second half of the eleventh millennium BP but the apparent discrepancy between $\mathrm{OxA}-170$ and -386 on the one hand, and OxA-407 and -473 on the other, has to be considered. We need to bear in mind that the AMS dates are on individual seeds and bones and, only by extension, date the levels in which they are found. The stratigraphic position of OxA170 and -386 could be accounted for through rodent or human activity. Both $0 \times \mathrm{A}-407$ and -473 are in the correct stratigraphic order in the dating sequence and each is from a level significantly below the surface of the Epipaleolithic settlement. Thus, there is a strong argument that these dates actually indicate when the levels were laid down. If this is accepted, then it would appear that the settlement was occupied until 10,000 BP. The length of time that the Epipaleolithic settlement was inhabited would thus be at least $1100{ }^{14} \mathrm{C}$ years. A more conservative estimate might be from 11,000 to $10,100 \mathrm{BP}$ but that still indicates that the settlement was occupied for nearly a millennium.

A date this late for the termination of Epipaleolithic occupation at Abu Hureyra is somewhat at odds with archaeologic expectations. Since the conclusion of excavations on the Euphrates, it has seemed probable that the Epipaleolithic settlement at Abu Hureyra was deserted before occupation commenced at Mureybat. This settlement was founded at the end of 
the Epipaleolithic, ca 10,450 BP (Phase I) on the chronology proposed by Cauvin (1977, p 48) based on a series of ${ }^{14} \mathrm{C}$ determinations for the site. The lunates at Abu Hureyra are almost all larger than those at Mureybat, a typologic variation that has been thought to reflect a chronologic distinction, and there are other differences in the material cultures of the two sites. The Mureybat dates are not without discrepancies and are, in any case, from samples of charcoal, so are likely to be significantly earlier than the stratigraphic events they date. Even allowing for this, it looks as though occupation of the two sites overlapped and our cultural expectations should be adjusted accordingly. It is already apparent that there were significant differences in the economies of these two sites, located on different sides of the Euphrates.

A further point should be made concerning the gazelle bone from the surface level of the Epipaleolithic settlement that gave an AMS date of $9060 \pm 140 \mathrm{BP}, \mathrm{OxA}-475$. The bone is much younger than the level from which it came that contained numerous Epipaleolithic flint artifacts; it is obviously intrusive from the overlying Neolithic levels. The date is most useful, however, because it is very close to BM-1719 from a slightly earlier level which gave a date of $9120 \pm 50 \mathrm{BP}$. Clearly, some bones and charcoal from the bottom of the overlying Neolithic levels became incorporated in the uppermost levels of the Epipaleolithic settlement. Since the dates confirm each other, they may be taken to indicate that the Neolithic settlement at Abu Hureyra expanded to cover the area around Trench E ca $9100 \mathrm{BP}$.

The AMS dates obtained by the Oxford Laboratory are a significant step forward in our research on the record from Abu Hureyra. Such precise dating of the duration of occupation of a site of this age is rarely achieved and it has implications, of course, for the dating of the Epipaleolithic stage in the Levant. More immediately, the successful application of the AMS technique to resolve problems concerning the botanical and faunal remains and the chronology of the Epipaleolithic settlement indicates that the technique will help us elucidate difficulties that have arisen in dating phases of occupation within the overlying Neolithic settlement.

\section{ACKNOWLEDGMENTS}

The Oxford Radiocarbon Accelerator Unit is supported by a Science and Engineering Research Council Research Grant. The authors wish to acknowledge the help of R Batten, A D Bowles, J F Foreman, R Gillespie, E Hendy, M J Humm, and A J Stoker.

\section{REFERENCES}

Batten, R J, Gillespie, R, Gowlett, J A J and Hedges, R E M, 1986, The AMS dating of separate fractions in archacology, in Stuiver, $M$ and Kra, R S, eds, Internatl ${ }^{14} \mathrm{C}$ conf, 12 th, Proc: Radiocarbon, v 28, no. 2A, p 691-697.

Burleigh, R, Ambers, J and Matthews, K, 1982, British Museum natural radiocarbon measurements XV: Radiocarbon, v 24, no. 3, p 262-290.

Burleigh, R, Matthews, K and Ambers, J, 1982, British Museum natural radiocarbon measurements XIV: Radiocarbon, v 24, no. 3, p 229-261.

Cauvin, J, 1977, Les fouilles de Mureybet (1971-1974) et leur signification pour les origines de la sedentarisation au Proche-Orient: Ann Am Schools Oriental Research, v 44, p $19-48$ 
Gillespie, R, Gowlett, J A J, Hall, ET and Hedges, R E M, 1984, Radiocarbon measurement by accelerator mass spectrometry: an early selection of dates: Archaeometry, v 26, no. 1, p 15-20.

Gillespie, R, Gowlett, J A J, Hall, E T, Hedges, R E M and Perry, C, 1985, Radiocarbon dates from the Oxford AMS system: Archaeometry datelist 2: Archaeometry, v 27, no. 2, p 237-346.

Hedges, R E M, 1981, Radiocarbon dating with an accelerator: review and preview: Archaeometry, v 23, no. 1, p 3-18.

Hedges, R E M and Gowlett, J A J, 1986, Radiocarbon dating by accelerator mass spectrometry: Sci American, v 254, no. 1, p 100-107.

Hillman, G C, 1975, The plant remains from Tell Abu Hureyra: a preliminary report, in Moore, AMT, The excavation of Tell Abu Hureyra in Syria: a preliminary report, $\mathrm{p} 70_{-}$ 73: Prehist Soc Proc, v 41, p 50-77.

Legge, A J, 1975, The fauna of Tell Abu Hureyra: preliminary analysis, in Moore, AMT, The excavation of Tell Abu Hureyra in Syria: a preliminary report, p 74-76: Prehist Soc Proc, v $41, \mathrm{p} 50-77$.

Legge, A J and Rowley-Conwy, P, in press, New radiocarbon dates for early sheep at Tell Abu Hureyra, Syria, in Gowlett, J A J and Hedges, R E M, eds, Archaeological results from accelerator dating: Oxford Comm Archaeol, Mono series.

Moore, A M T, 1975, The excavation of Tell Abu Hureyra in Syria: a preliminary report: Prehist Soc Proc, v 41, p 50-77.

1979, A pre-Neolithic farmer's village on the Euphrates: Sci American, v 241, p $62-70$. Schools Oriental Research Bull, v 246, p l-34.

1983, The first farmers in the Levant, in Young, T C, Jr, Smith, P E L and Mortensen, Peder, eds, The hilly flanks and beyond, Studies in ancient Oriental civilization no. 36: Chicago, Univ Chicago Press, p 91-111. 